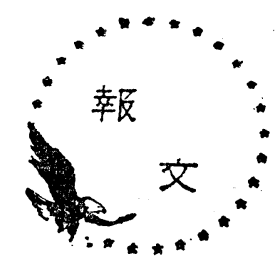

暖房器具における常磐炭の燃焼特性
常磐炭硡株式会社 吉 田威

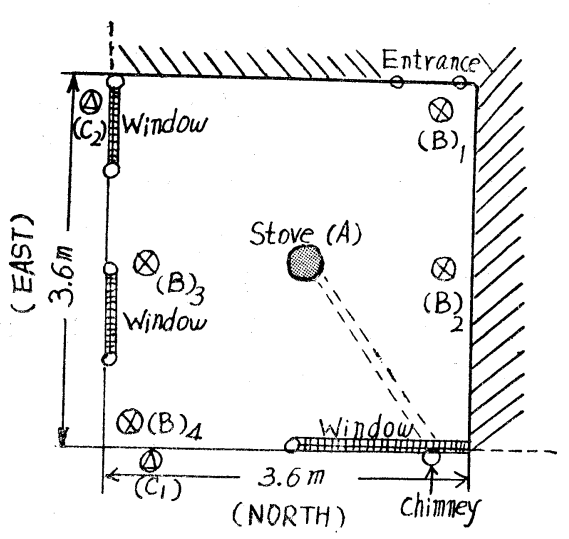

Fig. 1 Laboratory room

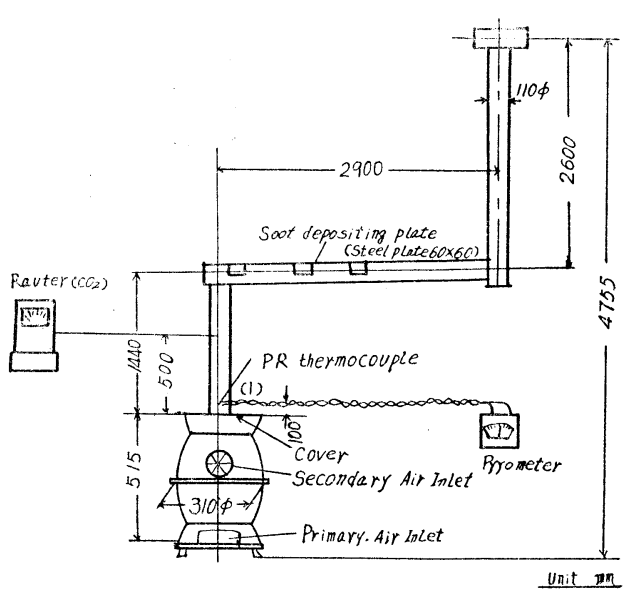

Fig. 2 Testing Apparatus

着板は煤が一般の煙突に附着する条件と同じ条件下に おくため燃燒ガスの流れと並例になるようハリガネに つるして位置した。

2. 試験方法および測定項目

ロストルの上に定量の赤熱した木炭をのせ直ちに定 量の石炭を投入し上蓋を閉じて試験開始時とし測定を 
開始する。この場合 1 次空気孔は開放し自然通風の条 件下に扔いて試験を継続する。燃焼ガスの $\mathrm{CO}_{2} \%$ が $5 \%$ になつた時をもつて試験終了時とする。燃焼が完 全に終り火気がなくなつてから燃えがらを取出す。測 定項目はつぎのごとし。

1) 燃焼ガス温度

白金一白金ロジウム熱電刘温度計により 2 分間 隔で測定する。

2) 燃焼ガス中の $\mathrm{CO}_{2}$

ラウター $\mathrm{CO}_{2}$ 計により 2 分間隔で測定する。

3) 煤煙温度

リンゲルマン濃度表と対比観察し 1 分毎に記録 する。

4）煤の附着量

煙突内の箇所に $60 \mathrm{~mm}$ 角のブリキ板を 3 枚吊

下げ試験終了後その面に附着した煤の量を天秤に て測定する。

5）外気温度および室内温度

アルコール棒状寒暖計で測定し 4 分毎に記録す る。

6）もえがら量

もえがら全量を上亚天科で科量する。

3. 燃焼特性值の意義

家庭用炭として問題となる燃燒特性はつぎのような ものと考える。

1）着火の良否 (着火時間)

2) 火持ちの長短 (火持時間)

3) 煤附着量の多宣 (煤量)

4）煙の濃度

5）燃えがら量の多寡（扊量）

6）放熱力の強弱

以上の特性值をつぎのごとく定義した。

(1) 着火時間 (Ignition time)

石炭は加熱されると揮発分を発生する。揮発分中の 可燃分は着火温度に達すると瞬間的に点火し燃焼を開 始する。燃焼が開始されると燃焼ガスの温度が急激に 上昇する。この現象を利用しつぎの方法によつて着火 時間を Fig. 3 の燃焼ガス温度グラフより判定した。

$A-B$ 間は石炭の未着火期間とし, $D-C$ 間の直線 部分を延長して横軸と交わつた点を求め着火時間と する。

(2) 火持時間 (Burning time)

着火して燃焼が促進するに従い揮発分の燃焼が終了 しオキ燃焼に移る。時間の経過につれて，燃焼は次第 に弱り新給炭の必要が生じてくる。新たに供給する石
炭がオキによつて着火し得る最低限界点までの時間を 火持時間と定義しその時期は $\mathrm{CO}_{2} \%$ の值で判定し た。すなわち予備実験により $\mathrm{CO}_{2} \% ， 5 \%$ の時をも つて新給炭時と決定した。(Fig. $3 C^{\prime}-F^{\prime}$ 間が火持時 間となる)。

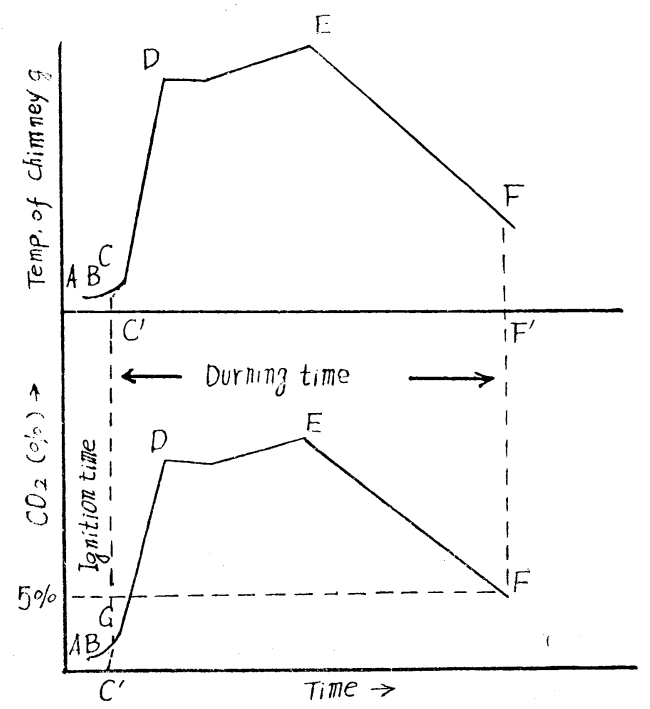

Fig. 3 Temprature of Chimney gas

(3) 煤附着量, (soot deposit rate)

煤の附着量は燃焼時において附着した全量を測定す るのが最む合理的と考えるが試験装置の性質上不可能 なのでつぎの方法によつた。予め予備試験によつて最 も煤の附着量の多い個所を調査しその部分に $60 \mathrm{~mm}$ 角のブリキ板 3 個を吊下げそのブリキ板に附着した煤 量を測定し煤附着量とした。

(4) 煙の濃度 (Smokeness)

リンゲルマン濃度表を並立して設置し $10 \mathrm{~m}$ の位置 より煙の発生状態を比較観察しつぎの方式により煙の 濃度率を求めた。

$\begin{array}{ccc}\text { 濃度表 No. } & & \text { 発生時間 }(\mathrm{sec}) \\ 1 & \times & T_{1}=A_{1} \\ 2 & \times & T_{2}=\mathrm{A}_{2} \\ 3 & \times & T_{3}=A_{3} \\ 4 & \times & T_{4}=A_{4} \\ 5 & \times & T_{5}=A_{5} \\ \text { 計 } & & \sum T \quad \sum A \\ \text { 煤煙濃度率 }=\frac{\sum A}{\sum T} \times 20(\%)\end{array}$

（5）燃えがら量 (Residue)

石炭を安全に灰化せしめその重量を測定した。 
（6）室内温度上昇 (Rate of room temperature rising)

室内温度計をストーブの輻射熱を避けた場所に置き 室内温度の上昇を記録した。その曲線は概ね Fig. 4 のごとくなるので着火点 $A$ を原点とし弧 $C$ 部に接 線 $A-B$ を引きその 上昇角度の $\tan \theta$ を求め室内温 度上昇率とする。從つてこの值が大なる程温度上昇速 度は早い。

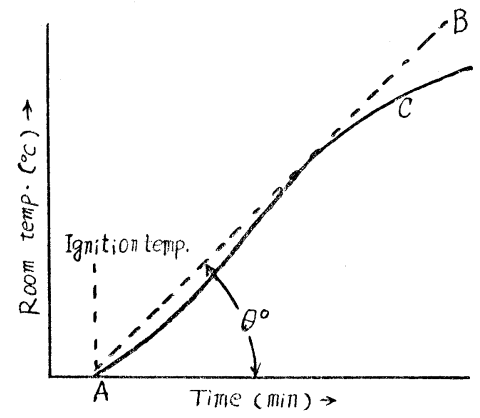

Fig. 4 Room Temprature

（7）放熱力 (Average temperature of chimney gas)

ストーブの放熱は輻射による割合が主たるものであ り，この輻射熱は絶対温度の 4 乗に比例することから
燃焼ガス温度が高い程輻射による放熱力は強いと考え られる。従つて放熱力の大小は燃焼ガス温度によつて 代行されるものと考え, Fig. 3 燃燒ガス温度のグラフ から $C^{\prime}-D-E-F-F^{\prime}$ で囲まれた面積をプラニメータ 一で求めそれを火持時間で除した值を放熱力を示す指 数とした。

（8）有効熱量係数 (Efficiently released calorie)

Fig. 3 燃焼ガス温度のグラフから $C^{\prime}-D-E-F-F^{\prime}$ で囲まれた面積をプラニメーターで求めた值は熱容量 的なものと考えることができる。従つてこの值を石炭 の発熱量で除すれば，石炭の持つ熱量の暖房に実際利 用された有効度を知る目安とすることができるものと 考え,この值を有効熱量係数と名付けた。

$$
\text { 有効熱量係数 }=\frac{\text { 平均燃焼ガス温度 } \times \text { 火持時間 }}{\text { 石炭の発熱量 }}
$$

（9）燃えがら中の未然分 (Combustible in residue) 燃えがらの中の未然分は次式より求めた。 然えがら中の未然分

$$
\begin{gathered}
=\frac{\text { 燃えがら重量 } \times \text { むがら中の未燃炭素 } \times 8100}{\text { 石炭の発熱量 }} \\
\quad \times 100(\%)
\end{gathered}
$$

II. 試験条件および試験結果

\begin{tabular}{|c|c|c|c|c|c|c|}
\hline \multirow{2}{*}{$\begin{array}{l}\text { Coals } \\
\text { as fired }\end{array}$} & \multirow{2}{*}{$\begin{array}{l}\text { Heating value } \\
\text { by calorimeter } \\
(\mathrm{kcal} / \mathrm{kg})\end{array}$} & \multicolumn{4}{|c|}{ Proximate Analyses } & \multirow{2}{*}{$\begin{array}{c}\text { *Ignition temp } \\
\text { (reactivity) } \\
\left({ }^{\circ} \mathrm{C}\right)\end{array}$} \\
\hline & & $\operatorname{Ash}(\%)$ & $\begin{array}{c}\text { Moisture } \\
\text { (\%) }\end{array}$ & $\begin{array}{l}\text { Volatile } \\
\text { matter } \\
(\%)\end{array}$ & $\begin{array}{l}\text { Fixed } \\
\text { carbon } \\
(\%)\end{array}$ & \\
\hline Nakagō & 5,040 & 14.60 & 16.20 & 37.30 & 31.90 & 353 \\
\hline Kaminoyama & 5,190 & 11.00 & 17.20 & 37.30 & 34.50 & 343 \\
\hline Nagakura & 6,100 & 13.50 & 9.30 & 43.50 & 33.70 & 369 \\
\hline Shin-nagakura & 5,680 & 15.40 & 10.90 & 40.60 & 33.10 & 375 \\
\hline Kushiro & 6,800 & 8.00 & 5.30 & 48.00 & 38.70 & 377 \\
\hline Sekiryū & 6,380 & 9.00 & 8.70 & 43.80 & 38.50 & 411 \\
\hline Ube & 5,750 & 13.10 & 9.80 & 41.60 & 35.50 & - \\
\hline
\end{tabular}

1. 試験炭の性状

Table. 1 Analyses and properties of coals as fired

* Ignition temperature; measured by ignition temperature apparatus by the method of differential thermal analysis. These show reactivity.

\section{2. 䳝験条件}

（1）試料の大きさは一般使用条件に近ずけるため と, できるだけ試験值が再現性あるようにするため $30 \sim 50 \mathrm{~mm}$ に整粒したものを使用した。

（2）試料の量はストーブの容量を勘案し，1回の試
験に $3 \mathrm{~kg}$ を使用した。

（3）着火材には着火の条件を一様にするために大き さおよび形状の揃つた木炭を選び，ロストル上一面に 配列きる量 $250 \mathrm{~g}$ をガスバーナーで赤熱させて使用 した。 
（4）ストーブの一次空気孔，二次空気孔および煙突 ダンパーを満開にし，自然通風とした。

（5）試験毎に煙突掃除を行ない通風および煤の附着 に対して同一条件を興えるようにした。
(6) $\mathrm{CO}_{2}$ 測定は試験終了時間の判定と着火時間の 判定の裏附けのために実施したので途中の測定は中止 した。

3. 試験結果

\section{Table. 2 Results}

\begin{tabular}{|c|c|c|c|c|c|c|c|c|c|c|}
\hline $\begin{array}{c}\text { Coals as } \\
\text { fired }\end{array}$ & $\begin{array}{l}\text { Ignition } \\
\text { time. } \\
\text { (min) }\end{array}$ & $\begin{array}{c}\text { Burning } \\
\text { time. } \\
\text { (min) }\end{array}$ & $\begin{array}{l}\text { Average } \\
\text { temp. of } \\
\text { chimney } \\
\text { gas }\left({ }^{\circ} \mathrm{C}\right)\end{array}$ & $\begin{array}{l}\text { Maximum } \\
\text { temp. of } \\
\text { chimney } \\
\text { gas. }\left({ }^{\circ} \mathrm{C}\right)\end{array}$ & $\begin{array}{c}\text { Smo- } \\
\text { keness } \\
(\%)\end{array}$ & $\begin{array}{l}\text { Soot } \\
\text { deposit } \\
\text { rate } \\
\text { (mg) }\end{array}$ & $\begin{array}{l}\text { weight of } \\
\text { residue } \\
\text { (g) }\end{array}$ & $\begin{array}{l}\text { Combu- } \\
\text { stible in } \\
\text { residue } \\
(\%)\end{array}$ & $\begin{array}{l}\text { Rate of } \\
\text { room te- } \\
\text { mp. rising } \\
\left({ }^{\circ} \mathrm{C} / \mathrm{min}\right)\end{array}$ & $\begin{array}{c}\text { Efficiently } \\
\text { released } \\
\text { calorie }\end{array}$ \\
\hline Nakago & 7.0 & 36.5 & 576 & 765 & 16.8 & 127.6 & 394 & 6.8 & 0.95 & 4.18 \\
\hline Kaminoyama & 7.2 & 33.5 & 610 & 760 & 16.6 & 118.0 & 377 & 5.8 & 0.96 & 4.06 \\
\hline Nagakura & 4.5 & 38.0 & 566 & 782 & 20.8 & 355.0 & 406 & 7.0 & 0.94 & 3.66 \\
\hline Shin-nagakura & ra 7.0 & 36.0 & 520 & 720 & - & 313.2 & 501 & 12.4 & 1.04 & 3.30 \\
\hline Kushiro & 4.7 & 47.2 & 568 & 775 & 20.6 & 351.5 & 296 & 4.6 & 0.89 & 3.91 \\
\hline Sekiryu & 4.7 & 36.0 & 650 & 780 & 20.0 & 302.4 & 272 & 10.3 & 0.96 & 3.67 \\
\hline Ube & 7.7 & 37.7 & 590 & 780 & 17.8 & 318.8 & 417 & 9.3 & 1.09 & 3.86 \\
\hline
\end{tabular}
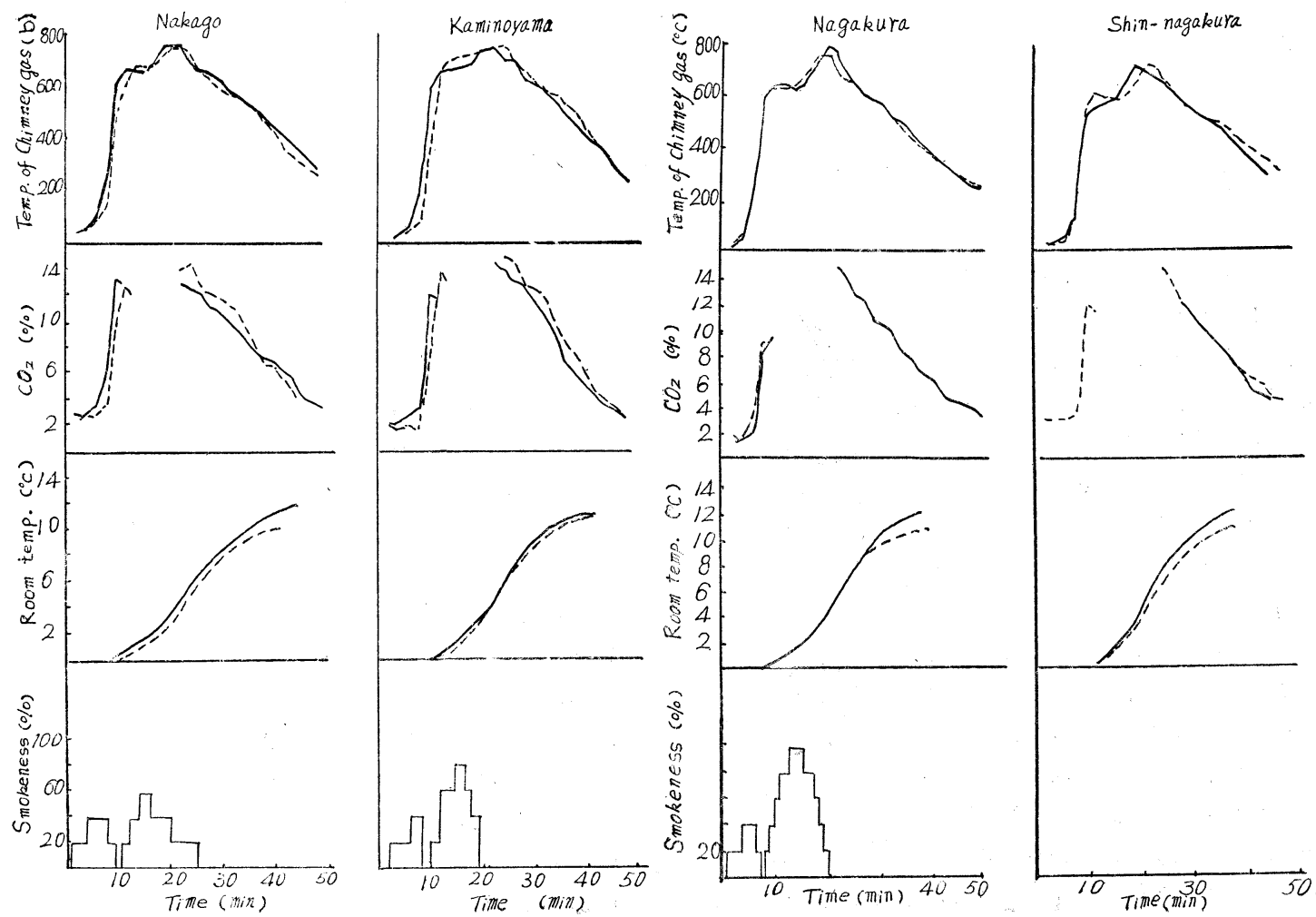

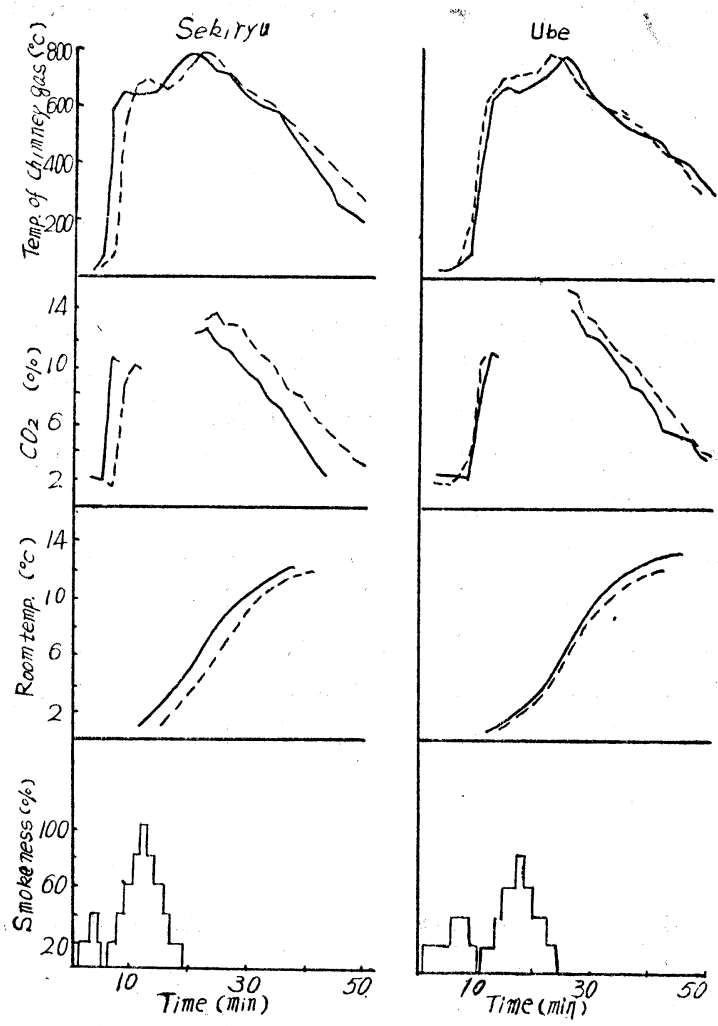

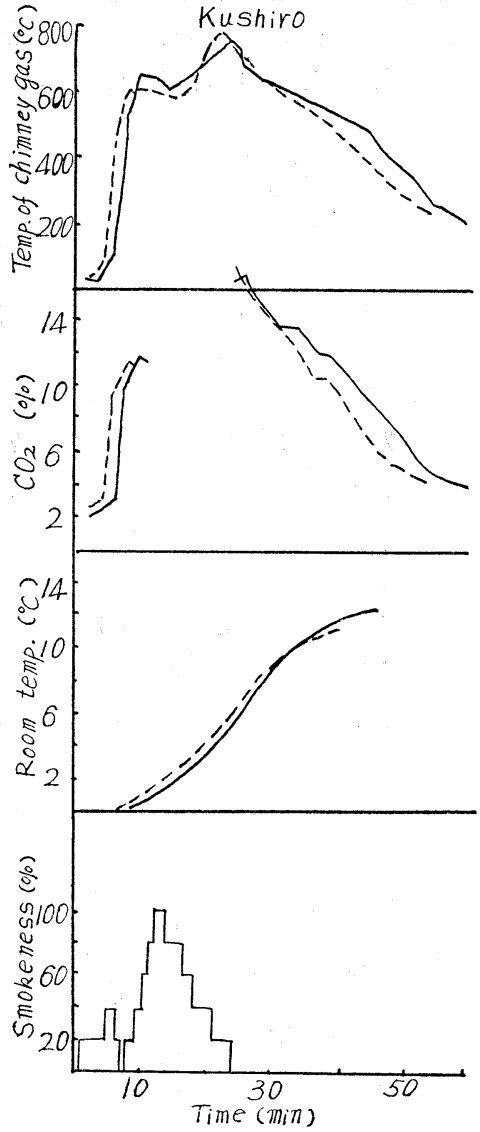

\section{III. 試験結果の考察}

1. 着火時間

一般に着火時間は発熱量の高低には余り影響されす 水分含有量によつて支配されるようである。すなわち 水分の多、石炭程着火時間は長い傾向が認められる。

水分含有量の多い中郷炭神の山炭は水分含有量の少 ない長倉炭や釧路炭, 石留炭に比較し着火時間が長い。

2. 火持時間

火持時間は石炭化度に比例して長い傾向がある。す なわち低石炭化度炭ほど火持時間は短い。これは低石 炭化度炭ほど反応性がよいために低温度で分解燃狫が 行なわれるためと考えられる。

3. 煙の温度および煤附着量

煙の濃度判定は肉眼的な観測であるため天候および 風速などによつて大きく影響されその判定は仲々困難 であつた。煙の色は中郷炭神の山炭のような低石炭化 度炭の場合褐色じみておりしかもその発生期間も短い が釧路炭，石留炭のように石炭化度の進んだ炭になる

と, 黒味が強くなり発生期間も長い。

煤の附着量は中郷炭，神ノ山炭は極端に少なく低石 炭化度炭ほど少ない傾向がある。一般的には水分の含 有量の多い石炭は媒の附着量が少ないと考えてよい。

4. 然えがらの重量

然えがらの多寡は一般家庭においては容量でもつて 制定される傾向が強い。従つて量的には死分の量にほ ぼ比例して多くなつているが石炭によつて然えがらの 性状が異なるため容量でもつて判定する場合その傾向 は異なつてすなわち崩潰性のよい石炭は容量が少な く，したがつて同一灰分量でも一般に灰の少ない石炭 のごとく考えられ非常に有利である。中郷，神ノ山炭 の燃えがらは崩潰性がよく一般に取り扱い易い。石留 炭は最もよい崩潰性を示した。

5. 放熱力と室内温度上昇率

室内温度上昇率は試験室が完全に密閉された部屋で 
なかつたため, 外気の度や風などの外気の条件の影響 によつて大きく左右され信頼性に乏しいものと考光 る。従つて室内温度上昇率はその值の性質上放熱力に よつて代行されるものと考えられるので石炭の室を諼 める能力を放熱力によつて判定し, 室内温度上昇率は 単にそれに対する参考資料とした。

放熱力は石炭の反応性と発熱量によつて支配される 発熱量の低い石炭であつても反応性のよい石炭は放熱 力は強い。これは反応性のよい石炭は単位時間に打け る熱発生率が多いためであろう。5,000 cal 程度の中 郷炭, 神ノ山炭が 7,000 cal に近い北海道炭に比較し 大差ない值を示しているのは反応性のよいことが影響 しているものと考えられる。

\section{6. 有効熱量係数}

反応性のよい石炭ほど高い傾向を示している。これ は, 反応性のよい石炭は然え切りがよく, ガスや灰中 の未燃損失が少ないことに基因するものであろう。 Table. 1 の燃えがら中の未燃分の值がこれをよく裏 附けしている。

\section{結論}

試験結果をみると各銘柄間において着火性（着火時 間）火持性（火持時間）ともほとんど大差がなく反面
煤煙附着量と然えがら量については大きな差が認めら れる。一般需要家が暖房炭を選定する場合着火性や火 持性を余り問題にせず煙突掃除の回数を支配する媒の 附着量と，捨て場に困る燃えがらの量の多宾を取りあ げているが今回の試験結果はこの需要家庭の暖房炭選 定条件の妥当性を充分裏附けしている。

放熱力についてはほぼ発熱量に比例するものと考え られたが石炭の反応性が発熱量に匹敵する程大きな影 響を及ぼす傾向があることが認められた。すなわち神 ノ山炭, 中郷炭のごとき低発熱量の石炭が $1,000 \mathrm{cal}$ もの相違がある高発熱量炭以上によい放熱力を示して いる。このようなことから考えると神ノ山炭，中郷炭 は発熱量泜低いが泠寒地区に扔いても充分利用可能で あり特にハウスールとして優れた特性を有していると 考えられる。

一般需要家の石炭の燃焼特性に対する認識は薄く, 石炭の種類によつて特性值に大きな開きがあることは 余り知られていない。競合燃料の進出の激しい現在石 炭の持つ特性に対する充分なる解説宜伝がハウスコー ル需要安定に対する最む重要な対策であるうと信ず る。

\title{
Combustibility of Joban Coal in Use for Heating Apparatus
}

\author{
by Takeshi Yoshida
}

(Joban Coal Mining Co., Ltd.)

SYNOPSIS : - Many researches and investigations have been reported on the combustibility of coal for industrial uses, while very few are carried out on house-coal to be used for home heating or for bath heating. This paper describes the combustibility of coal as house-coal, as per which following conclusions are given :

(1) Combustibility varies greatly with kinds of coal.

(2) Ignitability and burning time are little different with kinds of coal.

(3) There is a great difference in the amounts of soot and refuse.

(4) Heat release is affected severely by the reactivity of coal. 